\title{
Metabolism Energy, Nitrogen Retention, and Mineral Retention of Phosphorus Calcium and Zinc of Sugarcane Juice in Broilers
}

\author{
Ermin Widjaja ${ }^{1}$, Toharmat $\mathrm{T}^{2}$, Santosa $\mathrm{AD}^{1}$, Sumiati $^{2}$, Ridla $\mathrm{M}^{3}$ \\ ${ }^{I}$ AIAT of Central Kalimantan, Indonesian Agency for Agricultural Research and \\ Development, Pasar Minggu, Ministry of Agriculture. \\ ${ }^{2}$ Department of Nutrition Sciences and Technology of Animal Husbandry, Faculty of Animal \\ Science, Bogor Agricultural University. \\ ${ }^{3}$ Department of Soil Science and Land Resources, Faculty of Agriculture, Bogor Agricultural University.
}

\begin{abstract}
Poultry feed derived from grains has an anti-nutrient phytic acid. Naturally, phytate forms a complex bond with some minerals ( $\mathrm{P}, \mathrm{Zn}, \mathrm{Fe}, \mathrm{Mg}$, and $\mathrm{Ca}$ ), protein, and amino acids. The mineral-phytate complex cannot be absorbed by the small intestine of non-ruminant livestock and will adversely affect the availability of minerals in the ration. One way to improve the efficiency of mineral and protein utilization from phytate is using phytase. Sugarcane juice containing nutrients and phytase is very potential as liquid supplement for broiler chickens as it can hydrolyze phytic acid. The purpose of this study was to determine the retention of nitrogen, metabolism energy, and retention of minerals (P, Ca and $\mathrm{Zn}$ ) of sugarcane juice in broilers. The study was conducted for 7 days using metabolism cages for 28 broilers of 5 weeks old with 6 treatments of 4 replications, 4 for endogenous. The results showed that the administration of $2.5 \% / \mathrm{kg}$ sugarcane juice in the ration as well as in $2.5 \% /$ liter sugarcane juice in drinking water could provide the same result as giving commercial phytase $250-500$ FTU/kg on the retention of nitrogen, metabolizeable energy, and retention of minerals $\mathrm{P}, \mathrm{Ca}$ and $\mathrm{Zn}$.
\end{abstract}

Keywords - Sugarcane Juice; Metabolism Energy; Nitrogen Retention; Mineral; Retention.

\section{INTRODUCTION}

In animal husbandry, feed is an important factor in determining production and costs. Therefore, it is crucial to carry out proper selection of feed ingredients to produce quality feed that is able to meet the needs of livestock and can reduce the cost of production. The quality of highquality feed can lead to high feed prices. An alternative that can be done to overcome this obstacle is to use the available local feed ingredients without neglecting the quality of the feed ingredients. As it is known thatthe feed ingredients for poultry consist of energy and protein sources. One of the local feedstuffs with nutrient content is sugarcane.

Sugarcane (Saccharum officinarum L) is an important crop because it is an industrial plant that provides $65 \%$ of the world sugar needs. In addition, sugarcane juice contains many nutrients and functional compounds such as sucrose, monosaccharide, non-nitrogen organic acids, complex organic compounds, nitrogen compounds, inorganic compounds, dyes and lipids (Widjaja et al., 2011; Risvan, 2008). Sugarcane juice also contains the phytase enzyme with as activity of 0.0862 FTU / ml (Widjaja et al., 2011). Phytase enzyme serves to break down the $\mathrm{P}$ complex bonding and thus $\mathrm{P}$ will be used optimally. Poultry feed derived from grains has an anti-nutrient called phytic acid. Naturally, phytate forms complex bonds (chelates) with some mineral valence II ( $\mathrm{P}, \mathrm{Zn}, \mathrm{Fe}, \mathrm{Mg}, \mathrm{Ca})$ (Erdman and Schneier, 1989), protein, and amino acids (Nagashima et al., 1999; Wyss et al., 1999; Kerovuo, 2000; Quan et al., 2001). Phytate complex forms with minerals cannot be absorbed by the small intestine of non-ruminant livestock and will adversely affect the availability of minerals in the ration (Bedford and Partridge, 2001). The high phytate content in grains leeds to low utilization of $\mathrm{P}$ and other elements by non-ruminant livestock and results in adeficiency of $\mathrm{Zn}, \mathrm{Fe}$, $\mathrm{Mg}$, and $\mathrm{Ca}$. One way to improve the efficiency of utilization of $\mathrm{P}$ element from phytate is the use of phytase (Widjaja et al., 2011; Sumiati, 2005; Sanberg et al., 1996). Sugarcane juice containing nutrients is potentially good to be used as a liquid feed supplement for broilers although research on the use of sugarcane juice has not been reported, except for studies on using the byproducts of sugar processing for livestock feed. Among the sugar processing byproducts are molasses, extracted molasses (sugar cane extract / SCE), filter cake, sugarcane bagasse and shoots. Although the nutrient content of sugarcane juice is good, 
further research is still needed concerning protein digestibility, metabolism energy, corrected metabolism energy and mineral digestibility from sugarcane juice supplements in the ration and sugarcane juice in the drinking water for broilers.

\section{MATERIALS AND METHODS}

\section{A. Materials}

The test on metabolism energy used modified Farrell method (1978), using 6 feed treatments. Sugarcane juice used were PS 851 and IPB 1-3 varieties and the observed variables were indistinct metabolism energy, nitrogen corrected indistinct metabolism energy, pure metabolism energy, nitrogen corrected pure metabolism energy, indistinct retention of nitrogen, phosphorus, zinc, and calcium. The broiler chickens used were 28 aging 5 weeks, divided into 6 feed treatments with 4 replications, 4 chickens for the endogenous analysis. Data obtained were analyzed by the completely randomized design of $6 \times 4$, followed by DMRT (Duncan's Multiple Range Test) (Steel and Torrie, 1991).

\section{B. Methods}

The test on metabolism energy used modified Farrell method (1978). Before the treatments the rations were analyzed for the proximate content by AOAC methods (1999), phytate and phytase contents. Ration composition and nutrient treatments are presented in Tables 1 and 2.

TABLE I

. THE COMPOSITION RANSOM OF THE RESEARCH FOR BROILER CHICKEN AGING FIVE WEEKS

\begin{tabular}{lrrrrrr}
\hline \multirow{1}{*}{ Feed stuff } & \multicolumn{7}{c}{ The ransom of treatments } \\
\cline { 2 - 7 } & P 1 (control) & P 2 & P 3 & P 4 & P 5 & P 6 \\
\hline Grinding com (\%) & 58.00 & 58.00 & 58.00 & 58.00 & 58.00 & 58.00 \\
Rice bran (\%) & 9.00 & 9.00 & 5.40 & 5.40 & 5.40 & 9.00 \\
Soybean cake (\%) & 19.60 & 19.60 & 20.55 & 20.55 & 20.55 & 19.60 \\
MBM (\%) & 9.00 & 9.00 & 9.00 & 9.00 & 9.00 & 9.00 \\
Palm oil (\%) & 3.45 & 3.45 & 3.60 & 3.60 & 3.60 & 3.45 \\
Premix (\%) & 0.50 & 0.50 & 0.50 & 0.50 & 0.50 & 0.50 \\
DL-Methionine (\%) & 0.35 & 0.35 & 0.35 & 0.35 & 0.35 & 0.35 \\
NaCl (\%) & 0.10 & 0.10 & 0.10 & 0.10 & 0.10 & 0.10 \\
Sugarcane juice in ransom (\%/kg) & 0.00 & 0.00 & 2.50 & 2.50 & 2.50 & 0.00 \\
Sugarcane juice in water (\%/liter) & 0.00 & 0.00 & 0.00 & 0.00 & 0.00 & 2.50 \\
Commercial phytase (FTU/kg) & 0.00 & 500 & 500 & 250 & 0.00 & 0.00 \\
\hline Total & 100.00 & 100.00 & 100.00 & 100.00 & 100.00 & 100.00 \\
\hline
\end{tabular}

TABLE II

THE NUTRIENT COMPOSITION OF THE RANSOM TREATMENTS FOR BROILER CHICKEN AGING FIVE WEEKS

\begin{tabular}{|c|c|c|c|c|c|c|c|}
\hline \multirow{2}{*}{$\begin{array}{c}\text { Nutrient } \\
\text { containing }\end{array}$} & \multicolumn{6}{|c|}{ The ransom of treatments } & \multirow{2}{*}{$\begin{array}{l}\text { Requirement } \\
\text { (Lesson and Summer } \\
\text { 2005) }\end{array}$} \\
\hline & $\begin{array}{c}\text { P1 } \\
\text { (control) }\end{array}$ & P2 & P3 & P4 & P5 & P6 & \\
\hline $\begin{array}{l}\text { Gross Energy } \\
\text { (kkal/kg) }\end{array}$ & 3106.50 & 3106.50 & 3103.60 & 3103.60 & 3103.60 & 3106.50 & 3100.00 \\
\hline Crude Protein (\%) & 20.00 & 20.00 & 20.00 & 20.00 & 20.00 & 20.00 & 20.00 \\
\hline Crude Fiber (\%) & & 2.63 & 2.39 & & & & \\
\hline Crude Fat (\%) & 6.65 & & & 6.64 & 6.64 & 6.65 & \\
\hline $\mathrm{Ca}(\%)$ & 0.77 & 0.77 & 0.77 & 0.77 & 0.77 & 0.77 & 0.92 \\
\hline P available (\%) & 0.23 & 0.23 & 0.20 & 0.20 & 0.20 & 0.23 & 0.41 \\
\hline Na $(\%)$ & 0.15 & 0.15 & 0.15 & 0.15 & 0.15 & 0.15 & 0.21 \\
\hline $\mathrm{Cl}(\%)$ & 0.19 & 0.19 & 0.19 & 0.19 & 0.19 & 0.19 & 0.15 \\
\hline $\mathrm{Zn}(\mathrm{mg} / \mathrm{kg})$ & 3892 & 38.92 & 3836 & 38.36 & 38.36 & 3892 & 7000 \\
\hline Lysine (\%) & 0.88 & 0.88 & 0.89 & 0.89 & 0.89 & 0.88 & 1.15 \\
\hline Methionine (\%) & 0.65 & 0.65 & 0.65 & 0.65 & 0.65 & 0.65 & 0.44 \\
\hline Methionine + & & & & & & & \\
\hline Cystine (\%) & 0.86 & 0.86 & 0.87 & 0.87 & 0.87 & 0.86 & 0.88 \\
\hline Threonine (\%) & 0.66 & 0.66 & 0.67 & 0.67 & 0.67 & 0.66 & 0.62 \\
\hline Tripthophan (\%) & 0.18 & 0.18 & 0.18 & 0.18 & 0.18 & 0.18 & 0.20 \\
\hline Phytic acid $(\%)$ & 1.30 & 1.30 & 1.38 & 1.38 & 1.38 & 1.30 & 0.00 \\
\hline
\end{tabular}

The ransom of treatment:

$P$ 1. Control ransom

P 2. Control ransom + phytase $500 \mathrm{FTU} / \mathrm{kg}$
P 3. Control ransom + phytase $500 \mathrm{FTU} / \mathrm{kg}+$ sugarcane juice $2.5 \% / \mathrm{kg}$

$\mathrm{P}$ 4. Control ransom + phytase $250 \mathrm{FTU} / \mathrm{kg}+$ sugarcane juice $2.5 \% / \mathrm{kg}$

P5. Control ransom + sugarcane juice $2.5 \% / \mathrm{kg}$

P 6. Control ransom + sugarcane juice 2,5\% /liter drinking water

1. The measurement procedures of metabolizeable energy and apparent retention of $N, Z n, P$, and $C a$ are as follows:

a. All chickens were fed with a commercial feed for 2 days.

b. On the 3rd day, all chickens were weighed and fasted for 24 hours of rations to eliminate the effect of previous rations but were still given a drink.

c. On day 4, 24 treated chickens were weighed, then fed ad libitum for 4 days. Each feeding was always weighed and on the last day the rest of the feed was weighed so that the amount of feed consumed was known. A total of four chickens for endogenous analysis remained fasted ( 2 days of fasting). All the metabolizeable cages were covered with plastic sheets to contain the excreta (feed and endogenous treatment chickens). After the first excreta came out, the pens were sprayed with $0.01 \%$ $\mathrm{H} 2 \mathrm{SO} 4$ as often as possible.

d. On day 5, all endogenous treatment chickens (4) were weighed and the excreta was collected, weighed and then put in a freezer for +24 hours. The excreta samples were put in the oven at $600 \mathrm{C}$ until they were dried, and then weighed, crushed while being cleaned of dirt. The excreta samples that have been dry, smooth and clean were then weighed and analyzed for the pseudo nitrogen retention (Kjeldal).

e. On day 7, all feed treatment chickens (24) were weighed, and the excreta was collected, weighed and put in a freezer for +24 hours. The excreta samples were put in the oven at $60 \mathrm{oC}$ until they were dried, and then weighed, crushed while being cleaned of dirt. The excreta samples that have been dry, smooth and clean were then weighed and analyzed for the contents of dry matter, metabolizeable energy (bomb calorimetry), minerals $\mathrm{Zn}$, $\mathrm{P}$ and $\mathrm{Ca}$.

f. Nitrogen Retention

- Nitrogen Consumption (g) This value was obtained by multiplying the amount of feed consumption with the nitrogen content of feed treatments.

- Nitrogen Excretion was obtained by multiplying the amount of excreta with the excreta nitrogen content Nitrogen Excretion $(\%)=\mathrm{N}$ Excretion $(\mathrm{g}) \times 100 \% \mathrm{~N}$ Consumption (g)

- NR - Nitrogen Retention (g), was the difference between nitrogen intake and nitrogen excreted value after correction to the value of endogenous nitrogen excretion.

Nitrogen Excretton $(\%)=\frac{\text { N Excretion }(g) \times 100 \%}{\text { N Consumption }(\mathrm{g})}$

Nitrogen Retention $(g)=N$ Consumption $-(\mathbb{N}$ excretion $-\mathbb{N}$ endogenous) 
Mirogen Retention $(\gamma)=\frac{N \text { Comsumption }-(\text { Nexcretion }-N \text { endogenous }) \times 100 \%}{N \text { Consumption }}$

g. Metabolizeable Energy ( $\mathrm{kcal} / \mathrm{kg}$ ) was calculated using the following formulas:

- Energy Consumption $=$ Feed Consumption $\mathrm{x}$ Gross Energy of Feed

- Energy Excretion = Total dry excreta $\mathrm{x}$ Gross Energy Content of Excreta

- Metabolism energy is the difference between the gross energy content of feed treatments and the gross energy lost through excreta

- Apparent Metabolism Energy (AME) (kcal / kg)

- $A M E=\frac{(E B \times X)-(E B e \times Y)}{X} 1000$

- True Metabolism Energy (TME) (kcal / kg)

- $\mathrm{TME}=\frac{(\mathrm{EB} \times \mathrm{X})-[(\mathrm{EBE} \times \mathrm{Y})-(\mathrm{SPE} \times \mathrm{Z})] \mathrm{X} 1000}{\mathrm{X}}$ $\mathrm{X}$

- Nitrogen Corrected Apparent Metabolism Energy (AMEn) (kcal $/ \mathrm{kg}$ ) - $A M E n=\frac{(E B \times X)-[(E B e \times Y)-(8.22 \times R N)] \times 1000}{X}$

- Nitrogen Corrected True Metabolism Energy (TMEn) (kcal/ kg)

- $\mathrm{TMEn}=\frac{(\mathrm{EB} \times \mathrm{X})-[(\mathrm{EBE} \times \mathrm{Y})-(\mathrm{SPE} \times \mathrm{Z})-(8.22 \times \mathrm{RN})] \mathrm{X} \times 1000}{\mathrm{X}}$

Explanation:

EB : Bruto energy of feedstuff

EBe : Excreta bruto energy

EBk : Endogenous bruto energy (Kcal/kg)

$\mathrm{X}$ : Ransom consumption (gram)

Y : Weight of broiler chickens excreta given feedstuff teatment (gram)

$\mathrm{Z}$ : Weight of broiler chickens excreta which were fasted

$\mathrm{RN}$ : Nitrogen retention (gram)

8.22 : Value correction as a uric acid $(\mathrm{kcal} / \mathrm{kg})$

h. Zn Retention (\%) was calculated using the following formula:

(Ration consumption $\mathrm{x} Z \mathrm{Zn}$ ration) - (total excreta $\mathrm{x} Z \mathrm{n}$ excreta) $\times 100 \%$ Ration consumption $\mathrm{x} Z \mathrm{Zn}$ ration

i. P retention (\%) was calculated using the following formula: (Ration consumption $\mathrm{x}$ P ration) - (total excreta $\mathrm{x}$ P excreta) $\mathrm{x} 100 \%$ Ration consumption $x P$ ration

j. Ca Retention (\%) was calculated using the following formula: (Ration consumption $\mathrm{x}$ Ca ration) - (total excreta $\mathrm{X}$ Ca excreta) $\times 100 \%$ Ration consumption $\mathrm{x} C \mathrm{Ca}$ ration

\section{Data Analysis}

Data obtained were analyzed by completely randomized design of $6 \times 4$, followed by DMRT (Steel and Torrie, 1991).

\section{RESULTS AND DISCUSSION}

\section{A. Nitrogen Retention}

The study results show that the consumption of all treatment rations is different from the control (Table 3). Ration treatments P2 and P5 have a high level of consumption. Consumption of $\mathrm{N}$ also significant $(\mathrm{P}<0.05)$ increases and the excretion of corrected nitrogen decreases, thus nitrogen retention will increase. Wahyu (1988) showed that the higher the ration consumption, the higher the nitrogen retention. Phytase supplementation and $2.5 \% / \mathrm{kg}$ sugarcane juice can increase consumption and nitrogen retention. Commercial phytase supplementation $500 \mathrm{FTU} / \mathrm{kg}$ and $2.5 \% / \mathrm{kg}$ sugarcane juice in the ration did not differ $(\mathrm{P}>$ $0.05)$ in increasing nitrogen retention in the amount of $72.16 \%$ and $65.08 \%$. Thus, statistically the addition of sugarcane juice of $2.5 \% / \mathrm{kg}$ in broiler rations showed the same effect with the addition of commercial phytase on the level of use of $500 \mathrm{FTU} / \mathrm{kg}$.

TABLE III

THE AVERAGE OF RANSOM CONSUMPTION AND NITROGEN, EXCRETION AND NITROGEN RETENTION OF TREATMENT RANSOM.

\begin{tabular}{|c|c|c|c|c|c|c|}
\hline \multirow[t]{2}{*}{ Vanables } & \multicolumn{5}{|c|}{ Treatments } & \multirow[b]{2}{*}{ P6 } \\
\hline & $\mathrm{Pl}$ & $\mathrm{P} 2$ & $\mathrm{P} 3$ & P4 & P5 & \\
\hline Ransom consumption & $330.03^{5}$ & $575.77^{i}$ & $460.35^{h}$ & $428.87^{11}$ & $542.53^{a}$ & $453.50^{6}$ \\
\hline (ghead/5 days) & $(14.63)$ & $(35.70)$ & $(26.80)$ & (25.1) & (22.1) & $(19.51)$ \\
\hline N consumption & $59.41^{f}$ & $103.64^{4}$ & $82.85^{6}$ & $77.20^{11}$ & $97.66^{3}$ & $81.63^{b}$ \\
\hline (g/head/5 days) & $(2.63)$ & $(6.43)$ & $(4.82)$ & $(4.52)$ & $(3.98)$ & $(3.51)$ \\
\hline Nexcretion conrected & $20.65^{2}$ & $24.62^{2}$ & $1893^{\circ}$ & $20.05^{a}$ & $22.42^{\mathrm{a}}$ & $25.58^{2}$ \\
\hline (g/bead/5 days) & (4.84) & (2.93) & $(7.07)$ & $(5.00)$ & (2.79) & $(5.52)$ \\
\hline N Retention (\%) & $57.22^{4}$ & $98.51^{2}$ & $83.63^{b}$ & $76.13^{k e}$ & $94.46^{4}$ & $74.08^{\circ}$ \\
\hline & (7.19) & $(6.31)$ & $(4.77)$ & $(8.62)$ & $(4.12)$ & $(3.86)$ \\
\hline
\end{tabular}

Explanation: Different superscript in the same row explain differen $(\mathrm{P}<0.05)$. The numbers in the brackets are deviation standard.

Nitrogen retention in supplementation treatments of 500 FTU $/ \mathrm{kg}$ phytase and $2.5 \% / \mathrm{kg}$ sugarcane juice combination and $250 \mathrm{FTU} / \mathrm{kg}$ phytase and sugarcane juice supplementation of $2.5 \% / \mathrm{kg}$ combination increased by $46.16 \%$ and $33.05 \%$, while supplying sugarcane juice in drinking water was only able to increase nitrogenretention by $29.47 \%$ compared to controls. The increase of nitrogen retention in all treatments was due to phytase activity that can hydrolyze phytic acid and releaseprotein so that the hydrolysis results i.e. amino acids can be absorbed better.

Providing sugarcane juice previously mixed into the ration is more effective in increasing nitrogen retention than that directly given in drinking water. This is possible because the sugarcane juice mixed into the ration will first react with phytic acid present in the ration resulting in phytic acid hydrolysis process that releases minerals, proteins and vitamins so that when consumed it will be more easily utilized by livestock. When administered directly into drinking water, phytase will directly go into the gastrointestinal tract and is absorbed immediately so that the activity of phytase to hydrolyze phytic acid in the ration has shorter time and consequently the nitrogen retention result is lower than that given in mixed ration.

\section{B. Metabolism Energy}

The study results show that the increase in the ration consumption also resulted in the increase in energy consumption in all treatments (Table 4). Statistically the energy consumption of P2 (500 FTU/kg phytase supplementation) and P5 (sugarcane juice supplementation of $2.5 \% / \mathrm{kg}$ ration) did not differ $(\mathrm{P}>0.5)$ but different $(\mathrm{P}<$ 0.05 ) with the control, with an increase in energy consumption of $74.39 \%$ and $64.36 \%$ as well as an increase of energy excretion by $22.46 \%$ and $35.50 \%$ respectively. Providing 2.5\%/liter sugarcane juice in drinking water could increase the energy consumption by 
$37.39 \%$ and energy excretion increased by $34.06 \%$. The extent of energy excretion value may reflect the extent of rations that can be digested. The smaller the value of energy excretion is, the greater the ration that can be digested. In other words, the greater the energy excretion value is, the less ration that can be digested.

TABLE IV

THE AVERAGE OF CONSUMPTION, ENERGY EXCRETION AND METABOLISM ENERGY OF TREATMENT RANSOMS

\begin{tabular}{|c|c|c|c|c|c|c|}
\hline \multirow[t]{2}{*}{ Variables } & & \multicolumn{5}{|c|}{ Treatments } \\
\hline & P1 & P2 & P3 & P4 & P5 & P6 \\
\hline Energy consumption & $1316^{\mathrm{C}}$ & $2295^{\mathrm{a}}$ & $1835^{\mathrm{b}}$ & $1710^{b}$ & $2163^{a}$ & $1808^{b}$ \\
\hline (kcal/head/5days) & $(58)$ & (142) & (106) & (100) & (88) & (77) \\
\hline Energy excretion & $276^{\mathrm{b}}$ & $338^{\mathrm{ab}}$ & $296^{\mathrm{ab}}$ & $315^{\mathrm{ab}}$ & $374^{\mathrm{a}}$ & $370^{a}$ \\
\hline (kcal/head $/ 5$ day) & (35) & (34) & (67) & $(60)$ & (57) & (61) \\
\hline AME (kcal/kg) & $3151^{\mathrm{c}}$ & $3398^{a}$ & $3349^{\mathrm{ab}}$ & $3246^{a b c}$ & $3296^{a b c}$ & $3173^{b c}$ \\
\hline & $(105)$ & (67) & (113) & $(175)$ & (119) & $(100)$ \\
\hline AMEn (kkal/kg) & $\begin{array}{l}3149^{\mathrm{C}} \\
(106)\end{array}$ & $\begin{array}{l}3397^{\mathrm{a}} \\
(67)\end{array}$ & $3348^{\mathrm{ab}}$ & $\begin{array}{l}3245 \text { abc } \\
175)\end{array}$ & $\begin{array}{l}3295^{a b c} \\
(119)\end{array}$ & $\begin{array}{l}3172^{b c} \\
(100)\end{array}$ \\
\hline TME (kkal/kg) & $2981^{\mathrm{a}}$ & $3274^{\mathrm{a}}$ & $3172^{\mathrm{a}}$ & $3088^{\mathrm{a}}$ & $3109^{a}$ & $3009^{\text {a }}$ \\
\hline TMEn (kkal/kg) & $\begin{array}{l}(209) \\
2979^{\mathrm{a}}\end{array}$ & $\begin{array}{l}(114) \\
3272^{\mathrm{a}}\end{array}$ & $\begin{array}{l}(210) \\
3170^{\mathrm{a}}\end{array}$ & $\begin{array}{l}(232) \\
3086^{a}\end{array}$ & $\begin{array}{l}(103) \\
3108^{a}\end{array}$ & $3008^{a}$ \\
\hline & (209) & (114) & $(210)$ & $(232)$ & (103) & (153) \\
\hline
\end{tabular}

Explanation: The different of superscript in the same row explain different $(\mathrm{P}<0.05)$. The numbers in the brackets are deviation standari. AME : Apparent Metabolism Energy ; AMEn : Nitrogen Corrected Apparent Metabolism Energy; TME : True Metabolism Energy; TMEn : Nitrogen Corrected True Metabolism Energy.

Although statistically P4 (250 FTU/kg phytase supplementation $+2.5 \% / \mathrm{kg}$ sugarcane juice $), \mathrm{P} 5(2.5 \% / \mathrm{kg}$ sugarcane juice supplementation) and P6 (2.5\% / liter sugarcane juice supplementation in drinking water) treatments were not different from the control on the AME and AMEn, but could increase the values of AME by $3.01 \%$, $4.6 \%$ and $0.7 \%$ respectively, while AMEn increased by $3.05 \%, 4.64 \%$ and $0.73 \%$ respectively. Treatments of P2 (500 FTU/kg phytase supplementation) and P3 (500 FTU/kg phytase supplementation $+2.5 \% / \mathrm{kg}$ sugarcane juice) did not differ, but different from the control on the values of AME and AMEn. AME values in P2 and P3 treatments increased by $7.84 \%$ and $6.28 \%$, while AMEn increased by $7.88 \%$ and $6.32 \%$. AME value is higher than that of AMEn because the values AME are not nitrogen corrected while the values of AMEn had been corrected.

Statistically the values of TME and TMEn of all treatments were not different from the TME control value, but the TMA values of P2, P3, P4, P5 and P6 increased by $9.83 \%, 6.41 \%, 3.59 \%, 4.29 \%$ and $0.94 \%$, while the values of TMEn increased by $9.84 \%, 6.41 \%, 3.59 \%, 4.33 \%$ and $9.7 \%$ respectively. An increase in metabolizeable energy is due to the activity of phytase in all treatments supplemented with commercial phytase and phytase contained in sugarcane juice. Phytase can hydrolyzephytic acid in the ration treatments releasing minerals, proteins and vitamins. Protein resulted from the hydrolysis could be digested and produced energy so that metabolizeable energy increased.

The values of AME and TME highly depend on the gross energy consumed and gross energy excreted through excreta and also the endogenous gross energy. TME value which is the gross energy of feed ingredients reduced by the gross energy of excreta and endogenous gross energy has a higher value than the value of TMEn. This is because the value of TMEn has been nitrogen corrected.

\section{Mineral Retention}

The study results show that feed intake that increased significantly $(\mathrm{P}<0.05)$ was followed by the increase in the consumption of $\mathrm{P}, \mathrm{Ca}$ and $\mathrm{Zn}$ minerals compared to the control (Table 5).

TABLE V

THE AVERAGE OF CONSUMPTION, EXCRETION AND RETENTION OF P, CA AND ZN IN THE RANSOM OF TREATMENTS

\begin{tabular}{ccccccc}
\hline \multirow{2}{*}{ Variables } & \multicolumn{7}{c}{ Treatments } \\
\cline { 2 - 7 } & P 1 & P 2 & P 3 & P 4 & P 5 & P 6 \\
\hline P consumption & $2.44^{\mathrm{e}}$ & $4.26^{\mathrm{a}}$ & $3.52^{\mathrm{c}}$ & $3.18^{\mathrm{d}}$ & $4.01^{\mathrm{b}}$ & $3.36^{\mathrm{c}}$ \\
(g/head/5 days) & $(0.11)$ & $(0.26)$ & $(0.190$ & $(0.18)$ & $(0.16)$ & $(0.15)$ \\
Ca consumption & $3.20^{\mathrm{c}}$ & $5.61^{\mathrm{a}}$ & $4.46^{\mathrm{b}}$ & $4.16^{\mathrm{b}}$ & $5.26^{\mathrm{a}}$ & $4.40^{\mathrm{b}}$ \\
(g/head/5 days) & $(0.14)$ & $(0.39)$ & $(0.39)$ & $(0.25)$ & $(0.22)$ & $(0.19)$ \\
Zn consumption & $15.27^{\mathrm{c}}$ & $26.64^{\mathrm{a}}$ & $21.29^{\mathrm{b}}$ & $19.84^{\mathrm{b}}$ & $25.10^{\mathrm{a}}$ & $20.98^{\mathrm{b}}$ \\
(g/head/5 days) & $(0.67)$ & $(1.65)$ & $(1.24)$ & $(1.16)$ & $(1.02)$ & $(0.90)$ \\
P excretion & $1.55^{\mathrm{a}}$ & $2.01^{\mathrm{a}}$ & $1.83^{\mathrm{a}}$ & $1.62^{\mathrm{a}}$ & $2.04^{\mathrm{a}}$ & $1.67^{\mathrm{a}}$ \\
(g/head/5 days) & $(0.20)$ & $(0.10)$ & $(0.62)$ & $(0.22)$ & $(0.30)$ & $(0.18)$ \\
Ca excretion & $2.43^{\mathrm{d}}$ & $4.15^{\mathrm{a}}$ & $3.00^{\mathrm{c}}$ & $2.83^{\mathrm{c}}$ & $3.69^{\mathrm{b}}$ & $3.07^{\mathrm{c}}$ \\
(g/head/5 days) & $(0.07)$ & $(0.34)$ & $(0.36)$ & $(0.06)$ & $(0.17)$ & $(0.12)$ \\
Zn excretion & $11.48^{\mathrm{b}}$ & $16.24^{\mathrm{a}}$ & $12.78^{\mathrm{b}}$ & $12.89^{\mathrm{b}}$ & $16.22^{\mathrm{a}}$ & $13.79^{\mathrm{b}}$ \\
(g/head/5 days) & $(0.85)$ & $(0.58)$ & $(3.99)$ & $(0.26)$ & $(0.56)$ & $(1.58)$ \\
P Retention (\%) & $36.77^{\mathrm{b}}$ & $52.61^{\mathrm{a}}$ & $46.90^{\mathrm{ab}}$ & $48.60^{\mathrm{ab}}$ & $49.38^{\mathrm{ab}}$ & $50.37^{\mathrm{ab}}$ \\
& $(5.59)$ & $(5.19)$ & $(16.39)$ & $(9.07)$ & $(6.14)$ & $(4.34)$ \\
Ca Retention (\%) & $23.95^{\mathrm{c}}$ & $25.67^{\mathrm{bc}}$ & $32.94^{\mathrm{a}}$ & $31.77^{\mathrm{a}}$ & $29.75^{\mathrm{ab}}$ & $30.23^{\mathrm{ab}}$ \\
& $(2.94)$ & $(3.13)$ & $(4.83)$ & $(3.35)$ & $(1.56)$ & $(1.91)$ \\
Zn Retention (\%) & $24.81^{\mathrm{b}}$ & $38.85^{\mathrm{a}}$ & $40.63^{\mathrm{a}}$ & $34.78^{\mathrm{ab}}$ & $35.34^{\mathrm{ab}}$ & $34.37^{\mathrm{ab}}$ \\
& $(4.80)$ & $(4.20)$ & $(16.49)$ & $(4.89)$ & $(1.60)$ & $(5.83)$ \\
\hline Explana)
\end{tabular}

Explanation: The different of superscript in the same row explain different

$(\mathrm{P}<0,05)$. The numbers in the brackets are deviation standard.

The amount of minerals that can be retained is greatly influenced by the amount of mineral excreted. The results show that the use of sugarcane juice in the ration as well as in drinking water can increase the retention of $\mathrm{P}$ and has no difference from the provision of $500 \mathrm{FTU} / \mathrm{kg}$ commercial phytase. P2 treatment using $500 \mathrm{FTU} / \mathrm{kg}$ commercial phytase gave the highest $\mathrm{P}$ retention i.e. 52.61\% increasing by $43.08 \%$ followed by P6 of $50.37 \%$ increasing by $36.98 \%$, followed by P5 of $49.38 \%$ increasing by $34.29 \%$, P4 of $48.60 \%$ increasing by $32.17 \%$, and $\mathrm{P} 3$ provided $\mathrm{P}$ retention of $46.90 \%$ increasing by $27.55 \%$ compared to the control.

The results also show that the retention of $\mathrm{Ca}$ increased by the provision of commercial phytase, sugarcane juice in the ration as well as in drinking water and the best result was obtained when given the combination of commercial phytase and liquid phytase sugarcane juice in the ration. The best $\mathrm{Ca}$ retentions consecutively were P3 of $32.94 \%$ increasing from $37.53 \%, \mathrm{P} 4$ of $31.77 \%$ increasing to $32.65 \%$, P6 of $30.23 \%$ increasing from $26.22 \%$, P5 of $29.75 \%$ increasing from $24.22 \%$ and P2 of 25.67 only increased by $7.18 \%$.

$\mathrm{Zn}$ retention is also influenced by the treatment using sugarcane juice and commercial phytase. The results show that $\mathrm{P} 2$ and $\mathrm{P} 3$ did not differ statistically, but the highest was $40.63 \%$ in $\mathrm{P} 3$ increasing to $63.73 \%$ and $38.85 \%$ in $\mathrm{P} 2$ increasing to $56.59 \%$. The next results of P5, P4 and P6 were $35.34 \%$ increasing to $42.44 \%$, $34.78 \%$ increasing to $40.18 \%$ and $34.37 \%$ increasing to $38.53 \%$ consecutively compared to the control.

An increase in mineral retention of $\mathrm{P}, \mathrm{Ca}$ and $\mathrm{Zn}$ was due to phytase activity contained in sugarcane juice and in the commercial phytase that can hydrolyze phytic acid ration releasing minerals $\mathrm{P}, \mathrm{Ca}$ and $\mathrm{Zn}$ originally in the complex bonds of phytic acid, so that the minerals became free available minerals that can be easily absorbed and retained by the body. The research results of Ceylan (2003); 
Keshavarz and Austic (2004), and Rutherfurd et al. (2002) show that administration of $750 \mathrm{U} / \mathrm{kg}$ phytase 90 - into feed can increase the retention of $\mathrm{P}, \mathrm{Ca}, \mathrm{Zn}, \mathrm{Cu}$ and $\mathrm{Mn}$ minerals.

\section{CONCLUSIONS}

Providing $2.5 \% / \mathrm{kg}$ sugarcane juice in the ration as well as $2.5 \%$ / liter sugarcane juice in drinking water can give the same result as giving 250-500 FTU/kg commercial phytase on the retention of nitrogen, metabolizeable energy, and the retention of $\mathrm{P}, \mathrm{Ca}$ and $\mathrm{Zn}$ minerals.

\section{ACKNOWLEDGMENT}

The authors would like to thank the Indonesian agency for agricultural research an development for tha funding through KKP3T all of the research

\section{REFERENCES}

[1] (AOAC) Association of Official Analytical Chemists. (1999). Official Methods of Analysis. Ed ke-16. Meryland USA: AOAC International.J.

[2] Bedford, M.R. and G.G. Patridge. 2001. Enzymes in Farm Animal Nutrition. CAB International

[3] Ceylan N, Scheideler SE, Stilborn HL. 2003. High availability phosphorus corn and phytase in layer diets. Poult Sci. 82 : 789-795.

[4] Erdman, J.W. and A. Poneros-Schneier. 1989. Phytic acid interactions with divalent cations in foods and in the gastrointestinal tract. In: Mineral Absorption in the Monogastric GI Tract (F.R. Dintzis and J.A. Laszlo, editors). New York : Plenum Press. Adv Exp Med Biol 249: 161-171.

[5] Farrell, D.J. 1977. A New, Rapid Method For Determining The Metabolizable Energy Of Poultry Feedstuffs. Department Of Biochemistry And Nutrition,University Of New England,Armidale, N.S.W. 2351.

[6] Kerovuo, J., Rouvine, J. and F. Hatzack. 2000. Analysis of myoinositol hexakisphosphate hydrolysis by Bacillus phytase: indication of a novel mechanism. Biochem J 352:623-628.
[7] Keshavarz, K and R.E. Austic. 2004. The use of low-protein, low phosphorus, amino acid and phytase supplemented diets on laying hen performance and nitrogen and phosphorus excretion. Poult Sci 83:75-83. Lesson, S. and J.D. Summers. 2005. Commercial Poultry Nutrition. 3rd ed. Nottingham University Press.

[8] Nagashima, T., Tange, T. and H. Anazawa. 1999. Dephosphorylation of phytate by using the Aspergillus niger phytase with a high affinity for phytate. Appl Environ Microbiol 65: 4682-4684

[9] Quan, C.S., Zhang, L.H., Wang, Y.J. and Y. Ohta. 2001. Production of phytase in a low hosphate medium by a novel yeast Candida krusei. J Biosci Bioeng 92:154-160.

[10] Risvan, K. 2008. Sukrosa dan sifatnya. http://www.risvank.com/2008/05/sukrosadan-sifatnya/ (29 Agustus 2010).

[11] Rutherfurd, S.M., T.K. Chung, P.C.H. Morel and P.J. Moughan. 2004. Effect of microbial phytase on ileal digestibility of phytate phosphorus, total phosphorus and amino acid in low-phosphorus diet for broiler. Poult Sci. 83: 61-68.

[12] Sandberg, A.S., Rossander-Hulthen, L. and M. Tuerk. 1996. Dietary Aspergillus niger phytase increases iron absorption in humans. J Nutr 126:476-480

[13] Steel, R.G.D. and J.H. Torrie. 1991. Prinsip dan Prosedur Statistik. Terjemahan. Edisi ke-2. Jakarta. Indonesia: Penerbit PT. Gramedia.

[14] Sumiati. 2005. Rasio molar asam fitat: Zn untuk menentukan suplementasi $\mathrm{Zn}$ serta penambahan enzim fitase dalam ransum berkadar asam fitat tinggi (disertasi). Bogor. Sekolah Pascasarjana, Institut Pertanian Bogor.

[15] Wahyu, J. 1988. Ilmu Nutrisi Unggas. Gadjahmada University Press.

[16] Widjaja, E., T. Toharmat, D. Santoso, Sumiati, dan M. Ridla, S.Iskandar. 2011. Potensi nira tebu sebagai suplemen cair dan arier enzim fitase untuk unggas secara in vitro. Jurnal Ilmu Ternak dan Veteriner. 16 (4):272-279.

[17] Wyss, M., Pasamontes, L., Friedlein, A., Remy, R., Tessier, M., Kronenberger, A.,Middendorf, A., Lehmann, M., Schnoebelen, L., Rothlisberger, U., Kusznir, E., Whl, G., Muller, F., Lahm, H.W. and K. Vogel. 1999. Biophysical characterization of fungal phytases (myo-inositol hexakisphosphate phosphohydrolases): molecular size, glycosylation pattern, and engineering of proteolytic resistance. Appl Environ Microbiol 65:359-366.97 